\title{
The growing chronic disease burden in Europe: a role for respiratory health professionals?
}

\author{
Nadia Kamel \\ Affiliations: European Respiratory Society, Brussels, Belgium.
}

Correspondence: N. Kamel, ERS Brussels Office, EU Affairs, Rue de Trèves 49-51, BE-1040, Brussels, Belgium. E-mail: nadia.kameldersnet.org

0

@ERSpublications

ERS calls for prevention, training and investments in personalised medicine at first EU Chronic Disease Summit http://ow.ly/usegS

The European Respiratory Society (ERS) started its policy work in the field of chronic diseases with the development of the European Respiratory Roadmap [1] under the ERS President, Marc Decramer (20102011). The European Respiratory Roadmap was launched at a pre-ministerial conference in 2010, during the Belgian Presidency of the European Union (EU), and shortly afterwards the very first council conclusions on chronic diseases were adopted [2]. This is also when the start of a reflection process on chronic diseases, initiated by the European Commission, began [3].

So what are chronic diseases? There is no established definition. According to the World Health Organization, chronic diseases have a long duration and a slow progression [4]. Examples of major chronic diseases are: cardiovascular diseases (including stroke), cancer, respiratory diseases, diabetes, kidney diseases and liver diseases. Although chronic diseases are both very common (responsible for $86 \%$ of all deaths in the $\mathrm{EU})$, and very costly, (responsible for up to $80 \%$ of all healthcare costs), they are also among the most preventable and can be effectively controlled $[5,6]$.

In a recent follow-up action, on December 10, 2013, the ERS launched the ERS/European Lung Foundation short policy-maker version of the European Lung White Book [7] the Lung Health in Europe: Facts \& Figures [8], at the Brussels Press Club (Brussels, Belgium). The publication provides key facts and figures on the state of European lung health - and the dire state it is in - an estimated 600000 people die every year in the EU from respiratory diseases; the total cost of respiratory diseases in the EU exceeds 380 billion euros [9]. The European Commissioner for Health, Tonio Borg, attended the event and gave a key note address (fig. 1) [10]. He acknowledged the respiratory community's call for comprehensive action on chronic diseases following the Commission's stakeholder consultation in April 2012. Commissioner Borg concluded his speech by inviting the ERS to the first EU summit on chronic diseases in Brussels on April 3 and 4, 2014 to move forward on this topic.

The summit on chronic diseases brought together several hundred EU policy makers, stakeholders, and interest groups to discuss medical, social and economic benefits of sustainable investments in health. There were debates on ways to reduce the burden of chronic diseases, and how to strengthen the prevention and management of chronic diseases, with a focus on EU added value and action.

The ERS President-Elect, Elisabeth Bel was invited to a workshop on April 3, 2014, entitled "Effective frameworks for the prevention and management of major chronic diseases". Asked to speak on multidisciplinary approaches for the prevention, treatment and control of chronic respiratory diseases, she

Received: Feb 192014 | Accepted: Feb 72014

Conflict of interest: Nadia Kamel is an employee of the European Respiratory Society.

Copyright (CERS 2014 


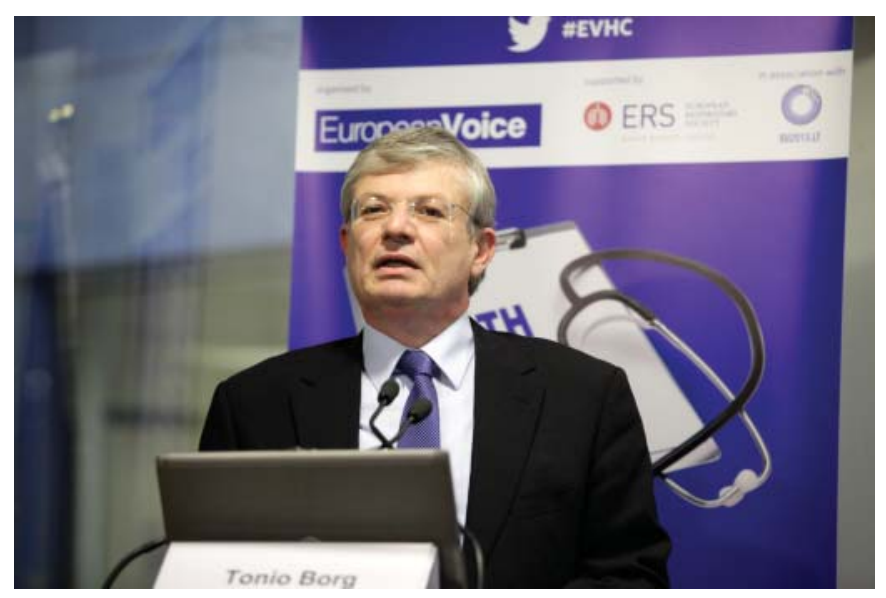

FIGURE 1 The European Commissioner for Health, Tonio Borg, presenting a key note address on December 10, 2013, at the high profile launch of the Lung Health in Europe: Facts \& Figures book [8], at the Brussels Press Club (Brussels, Belgium). The event was hosted by the European Respiratory Society (ERS) and officially endorsed by the Lithuanian Presidency of the European Union. The ERS President Peter J. Barnes was joined by the Lithuanian Deputy Health Minister Gediminas Černiauskas and Commissioner Borg at this important advocacy event.

focused her presentation on the changing face of the respiratory patient. Based on her many years of clinical practice she has witnessed how disease patterns have evolved over time. The reasons are multifactorial and complex; however a lot can be traced to the very different lifestyle of today compared to only a few decades ago, including exposure to a multitude of new and a modified range of risk factors [11].

Prof. Bel called upon the crucial and leading role that the EU can, and should, take in the field of prevention and the need to strengthen measures concerning major risk factors, which often underlie many chronic respiratory diseases (CRDs); relevant examples being asthma, chronic obstructive pulmonary disease, allergic rhinitis, cystic fibrosis, obstructive sleep apnoea, bronchiectasis, pulmonary fibrosis and occupational lung diseases. As a major world-leading body the EU has a vital role to improve air quality standards (outdoor and indoor) by following up member states on their implementation of smoke-free environments, improving occupational health and safety, and reducing health inequalities.

With regards to implementing multidisciplinary approaches for the treatment and control of chronic diseases, Prof. Bel stressed that greater understanding and more, improved, training across the lines of healthcare will be needed, because chronic respiratory diseases often affect several organs creating comorbid conditions. It is not uncommon that patients with CRDs have other coexisting conditions, such as osteoporosis, heart disease, and depression. An additional characteristic of CRDs is that they exist in many forms of severity, ranging from very mild to severe. Given these complexities, misdiagnosis by physicians is not uncommon leading to the wrong medication being administered for treatment.

Indeed, Prof. Bel emphasised that multidisciplinary integrated care models should be stimulated and funded, as these will be crucial for the optimal management of complex conditions. However, to achieve a successful implementation of multidisciplinary care for patients she reminded the audience, and policy makers, that it will be essential for professionals in respiratory care to educate not only respiratory specialists but also primary care physicians on how to best diagnose and treat CRD patients. As a clinician and researcher she expressed her hope in the potential of personalised medicine to curb costs for long-term treatment, illustrating the example of a recent breakthrough innovation targeting a specific asthma subphenotype using a novel anti-inflammatory treatment "anti-interleukin-5" that targets just one single receptor [12].

A core element for clinical research and to improve patient care and healthcare planning is the need for research infrastructures such as databases, and EU-wide disease registries. Prof. Bel proposed that organisations representing health professionals, such as the ERS, could be instrumental in leading the process to set up European-based disease registries for high-priority and well-defined chronic diseases, such as idiopathic pulmonary fibrosis or severe asthma. She suggested that the EU could add value in providing financial support for such activities.

The second day of the summit, April 4, 2013, consisted of a series of plenary sessions. The European Chronic Disease Alliance (ECDA), of which ERS is a member, was invited to speak at the opening session on the topic of "Stakeholder involvement as an asset in response to chronic diseases". Norbert Lameire, Chair 
of ECDA, emphasised the important role of this unprecedented alliance that brings together 11 not-forprofit organisations and represents the concerns of chronic disease patients and health professionals. He explained that ECDA's main mission is to speak with a unified voice, and provide policy makers with concrete evidence-based recommendations, advocating for policies that promote health, prevent disease and create healthier environments [13]. He underlined that the very reason these organisations had come together in 2010 was due to a growing awareness that all chronic disease are interrelated and linked to one another, and that similarly a more integrated and linked European strategy for chronic diseases will be needed to successfully address the many shared commonalties that chronic disease areas face. The summit ended with two more sessions - one on future needs, the other on possible responses and solutions - and a panel discussion about the EU added-value in this area, which included final recommendations and conclusions by Commissioner Borg.

We hope this article inspires readers to start their own reflection process about how healthcare professionals can contribute in discussions locally and nationally on: the medical, social and economic benefits of sustainable investments in health; ways to reduce the burden of chronic diseases; and how to strengthen the prevention and management of chronic diseases. The ERS will continue to follow and input into these discussions at European and international level, and provide our best expertise and knowledge on these pressing matters.

\section{References}

1 Decramer M, Sibille Y, eds. European Respiratory Roadmap. Sheffield, European Respiratory Society, 2011.

2 Council of the European Union. Council Conclusions: Innovative Approaches for Chronic Diseases in Public health and healthcare systems: 3053rd Employment, Social Policy Health and Consumer Affairs Council Meeting Brussels, 7 December 2010. Brussels, Council of the European Union, 2010. Available from: www.consilium.europa. eu/uedocs/cms_data/docs/pressdata/en/lsa/118282.pdf

3 European Commission, Directorate Health and Consumers: EU Reflection Process on Chronic Diseases. Brussels, Council of the European Union, 2012. Available from: http://ec.europa.eu/health/major_chronic_diseases/docs/ eu_reflection_cd_questionnaire_032012_en.pdf

4 World Health Organization. Health Topics: Noncommunicable Diseases. http://www.who.int/topics/noncommunicable diseases/en/ Date last accessed: March 11, 2014.

5 UNDESA/WHO Regional High-level Consultation: Addressing Non-Communicable Diseases: Major Challenges to Sustainable Development in the $21^{\text {st }}$ Century. Summary Report of the Meeting. UNDESA/WHO Regional Office for Europe, 2011. Available from: http://www.euro.who.int/_data/assets/pdf_file/0006/140739/NCD_Mtg_Oslo_ Apr2011_SumRep.pdf

6 Council of the European Commission. Reflection Process: Innovative Approaches for Chronic Diseases in Public Health and Healthcare Systems. Brussels, Council of the European Union, 2013. Available from: http://ec.europa. eu/health/major_chronic_diseases/docs/reflection_process_cd_final_report_en.pdf

7 Gibson GJ, Loddenkemper R, Sibille Y, et al., eds. European Lung White Book. Sheffield, European Respiratory Society, 2013.

8 Gibson JG, Loddenkemper R, Sibille Y, et al. eds. Lung Health in Europe Facts \& Figures. Sheffield, European Lung Foundation, 2013.

9 Gibson JG, Loddenkemper R, Sibille Y, et al. eds. The European Lung White Book Respiratory Health and Disease in Europe. Sheffield, European Respiratory Society, 2013.

10 Tonio Borg. Commissioner Tonio Borg delivers a speech on Respiratory Diseases: Launch of the "Facts and Figures Publication" of the Lung White Book 2013 by the European Respiratory Society. http://ec.europa.eu/ commission_2010-2014/borg/docs/speech_20131210_en.pdf Date last accessed: February 19, 2014. Date last updated: December 10, 2013.

11 Global Burden of Disease Study 2010: Executive Summary. http://www.thelancet.com/themed/global-burden-ofdisease December 13, 2012.

12 Chung KF. New treatments for severe treatment-resistant asthma: targeting the right patient. Lancet Respir Med 2013; 1: 639-652.

13 Optimising the Response to the Epidemic of Chronic Diseases. European Chronic Disease Alliance: Input to the reflection process on chronic diseases. http://www.alliancechronicdiseases.org/assets/docsforsite/pdfs/ECDA\%20input\% 20to\%20Reflection\%20Process\%20on\%20Chronic\%20Disease.pdf Date last accessed: February 19, 2014. 